\title{
Development of an Android-Based Sign Language Education Game Using a Scrum-Game Approach
}

\author{
Imam Fauzy Muldani Rachmat ${ }^{1}$, Gazali ${ }^{2}$ \\ ${ }^{1,2}$ Information System, STMIK Insan Pembangunan, Indonesia \\ ${ }^{1}$ imamfauzi43@ipem.ac.id, ${ }^{2}$ gazali37@ipem.ac.id
}

\begin{abstract}
Sign language is used as a communication tool for deaf children. It is also used by non-disabled as a way of communicating with them. However, not all nondisabled understand sign language since knowledge of sign language is required. Based on interviews among non-disabled and deaf people, including relatives and teachers, they experience miscommunication due to the lack of communication skills using sign language and rely only on lip movements. Sign language is applied to a subject in the State Special School of Banjar City, consisting of BISINDO and SIBI with conventional learning. This research to produce game products for learning sign language can help deaf children learn sign language in schools, especially non-disabled who want to learn sign language. The method used for developing games sign language education uses the SCRUM-Game approach, UML models, BlackBox testing, and usability testing. The sprint iteration consists of two sprints that produce educational sign language games: Alphabet SIBI and BISINDO. Educational game testing uses BlackBox testing with the conclusion that all functionality valid. Usability testing of student deaf responders and nondisabled respondents for efficiency, memorability, and errors is categorized as good. Aspect satisfaction and learnability get an excellent score. Overall, the resulting educational games get a good score. Therefore it is proper to be used.
\end{abstract}

Keywords: SIBI, BISINDO, sign language, SCRUMGAME, educational games

\section{INTRODUCTION}

Sign language in the special school education system is intended as a tool for learning and teaching. For example, both teachers and students in special schools (SLB) type B must use sign language. Therefore, sign language is not only used for communication between children with special needs (deaf), but it is used to communicate with non-disabled (not deaf), but the problem is not all non-disabled understand sign language because they have to study the alphabet in sign language first. Based on the interview results with non-disabled including teachers and relatives of deaf children in State Special School of Banjar, they had experienced miscommunication when communicating because they have not a knowledge of sign language, and instead relied on their efforts to read lip movements, which often led to misunderstandings. This finding was strengthened based on questionnaire data from 23 nondisabled respondents who had communicated with the deaf $91.6 \%$ of them did not speak sign language. The type of sign language used by deaf children is Indonesian Sign Language (BISINDO) and Sign Language system (SIBI) [1]. Both types of sign language are studied in sign language subjects at State Special School Banjar City. But deaf people often have difficulty using SIBI [2]. The State Special School student of Banjar prefers BISINDO to SIBI because the latter is more difficult. However, SIBI and BISINDO are still relatively unknown to non-disabled people. This was because the use of SIBI was done without the Indonesian Association's approval for The Welfare of The Deaf (GERKATIN) [3]. The characteristic that distinguishes SIBI from BISINDO is based on information from the Sign Language Teacher interview, namely BISINDO moves two hands to sign the alphabet, while SIBI only uses one hand. Sign language lessons are applied in the State Special School type B of Banjar using conventional methods. It seems that it is necessary to combine conventional methods with digital media, for example, by using a smartphone to introduce SIBI and BISINDO materials to sign language subjects to attract their interest [4]. Android-based smartphones have been widely used in State Special School Banjar City but have not been widely used to support classroom learning. Based on a questionnaire from 23 respondents of deaf children at the State Special School of Banjar City, $91 \%$ of respondents used smartphones to play non-educational games. Based on the research problem, than in previous research with the same research theme, namely ABAS (Let's Learn Prayer).: Prayer Learning Educational Game for Deaf Children at Special School type B of the Deaf Rehabilitation Foundation (YRTRW) Surakarta that produces Prayer learning media for the deaf and quizzes with a sequential approach, gameplay focuses on learning 
prayer reading [5]. In another study, the Android-Based Sign Language Learning Application produced a sign language learning media application using the Search Interpolation method used to translate words. So the user has to enter the word he wants to search for before it is finally translated [6]. The research entitled Android-Based Game Applications in Improving the Vocabulary Ability of Deaf Children uses a research and development model to produce learning games to recognize vocabulary with rules such as pictures of dragon flies children must choose letters that match the picture [7]. Another research, Development of Language Training Applications for the Deaf Using Google Speech based on Android, produced language training media designed using Java language programming by utilizing google speech (speech to text). So users use voice recognition that can precisely detect spoken words [8]. Therefore, based on previous research, it is necessary to develop aspects of the Scrum approach and development in terms of gameplay such as opportunities to play, scores, achievements, timers, proficiency in answering alphabets, and arranging letters into words based on SIBI and BISINDO sign language types, using random questions. Therefore, this research aims to produce game products for learning sign language to help deaf students learn SIBI and BISINDO at State Special School Banjar or nondisabled who want to learn sign language.

\section{METHOD}

This research is a case study research at the State Special School of Banjar by adopting the scrum approach to develop sign language educational games and be called the SCRUM-GAME approach. The SCRUM approach is a model of the Agile Development method and is not a technique for making products but a framework for managing products better [9][10]. There are three phases in the SCRUM approach, namely the Pre-Game (Defining), Games (Sprint development), Post-Games (Closure) phase, and the game development generally consists of the preproduction, production, and post-production stages [11] [12]. The following are the stages of game research that use the SCRUM approach, as shown in Fig. 1.

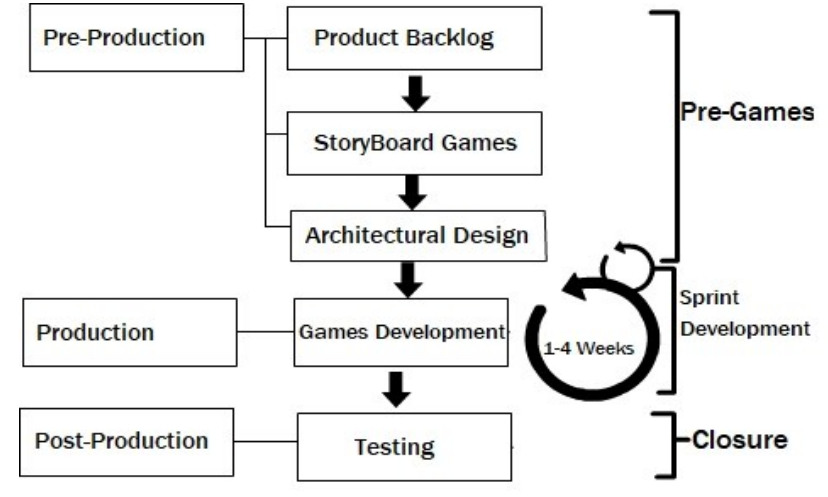

Fig. 1 Stages of sign language educational game development

\section{A. Pre-Production}

This stage begins with planning activities, namely conducting surveys and interviews with users, interviews with sign language teachers of State Special School of Banjar, and distributing questionnaires to 23 deaf student respondents and 23 non-disabled respondents, then followed by compiling a scrum team consisting of the product owner, scrum master, and development team to create a product backlog. The next process is analyzing needs and conceptualizing game ideas to determine product backlog items. The team can choose what features will be used as the first and next sprint through the product backlog [13]. The storyboard is made to facilitate development at the sprint stage. The purpose of storyboarding is to convey story ideas made in visual form from each scene that will be used as material for a project scenario [14]. The UML model is then used for sign language educational game architecture design activities. Sign language educational games use case diagrams to illustrate the functionality provided by the system in general. The sign language educational game activity diagram shows the system activity and the players who interact, such as how each action starts, any decisions, and until the activity is completed [15].

\section{B. Production}

This stage creates game asset materials based on the agreed product backlog needs. It is also to determine the Product Backlog Items selected for the sprint, which are added to deliver increments (Sprint Backlog). The game development stages use Construct 2, which is then broken down into several development processes. Each sprint will be stopped if there are no more changes and will continue to the next sprint stage. 


\section{Post-Production}

At this stage, the game application development has been completed. The next step is to test the sign language educational game. At this stage, the test is BlackBox testing, which is testing based on the application's functional specifications [16]. The test case design must have been completed to compare the test results output. Then, usability testing is carried out to determine the level of educational games that users can use. Nielsen's criteria are used to determine usability testing, such as learnability, efficiency, memorability, errors, and satisfaction [17]. The Likert scale method is applied to sign language educational games to make it easier to determine the results. The Likert scale applied is five-point scales, namely 1 to 5 [18]. The following is the Likert scale shown in Table I.

Based on Table I of the Likert scale, to determine the percentage of the criteria interval. The calculation process is carried out by dividing the total maximum value of the Likert scale by $100 \%$ then multiplying it by $100 \%$ so that the value of the interval is $20 \%$ [19].

\section{RESULTS AND DISCUSSION}

\section{A. Pre-Production}

Jenis huruf yang digunakan dalam naskah adalah Times New Roman, kecuali pada penulisan akun email. Jenis huruf lain dapat digunakan jika diperlukan untuk tujuan-tujuan tertentu.

1) Product Backlog: The activity carried out in the pre-production stage prepares the backlog product used for sprints at the next stage. This Backlog product is based on the ideas and concepts obtained. The development team can choose which features will be developed in the sprint backlog based on the product priority backlog. Number one indicates the priority developed in the first sprint iteration, and number two on priority will be developed in the second sprint iteration after the first sprint iteration. The following is the product backlog, which can be shown in Table II.

2) Storyboard Games: In building sign language educational games, it is necessary to explain the flow of the game. Therefore a game storyboard is made to clarify the plot. The storyboard contains a view of each extreme scene that will serve as a guide in programming the game flow [20]. Storyboard games in the pre-production stage are the final result of the script of the game story in the form of text called storyline. Storyline based on ideas and concepts so that it can be determined product backlog item features. Based on the product backlog item feature, the number of storyboard scenes in the Sign Language educational game is 12 scenes which will be developed in stages during the sprint iteration. The storyboard game is shown in Fig. 2.

3) Architectural Design of Games: At this stage, a sign language education game architecture was made using the UML model, namely the use case diagram. The following is a use case diagram shown in Fig.3 and an activity diagram to start playing games shown in Fig. 4.

TABLE I

LIKERT SCALE

\begin{tabular}{|c|c|c|}
\hline Answer & Value & Percentage (\%) \\
\hline Excellent & 5 & $81-100$ \\
\hline Good & 4 & $61-80$ \\
\hline Average & 3 & $41-60$ \\
\hline Poor & 2 & $21-40$ \\
\hline Very Poor & 1 & $0-20$ \\
\hline
\end{tabular}

TABLE II

PRODUCT BACKLOG

\begin{tabular}{ccc}
\hline $\begin{array}{c}\text { Id } \\
\text { Backlog }\end{array}$ & Feature Name & Priority \\
\hline 1 & SplashScreen & 2 \\
\hline 2 & Games Main Menu & 2 \\
\hline 3 & Select the Games Menu & 2 \\
\hline 4 & Select Learn menu & 2 \\
\hline 5 & Level 1:BISINDO Alphabet & 1 \\
\hline 6 & Level 1:SIBI Alphabet & 1 \\
\hline 7 & Level 2:Words BISINDO & 1 \\
\hline 8 & Level 2:Words SIBI & 1 \\
\hline 9 & Level Complete & 1 \\
\hline
\end{tabular}




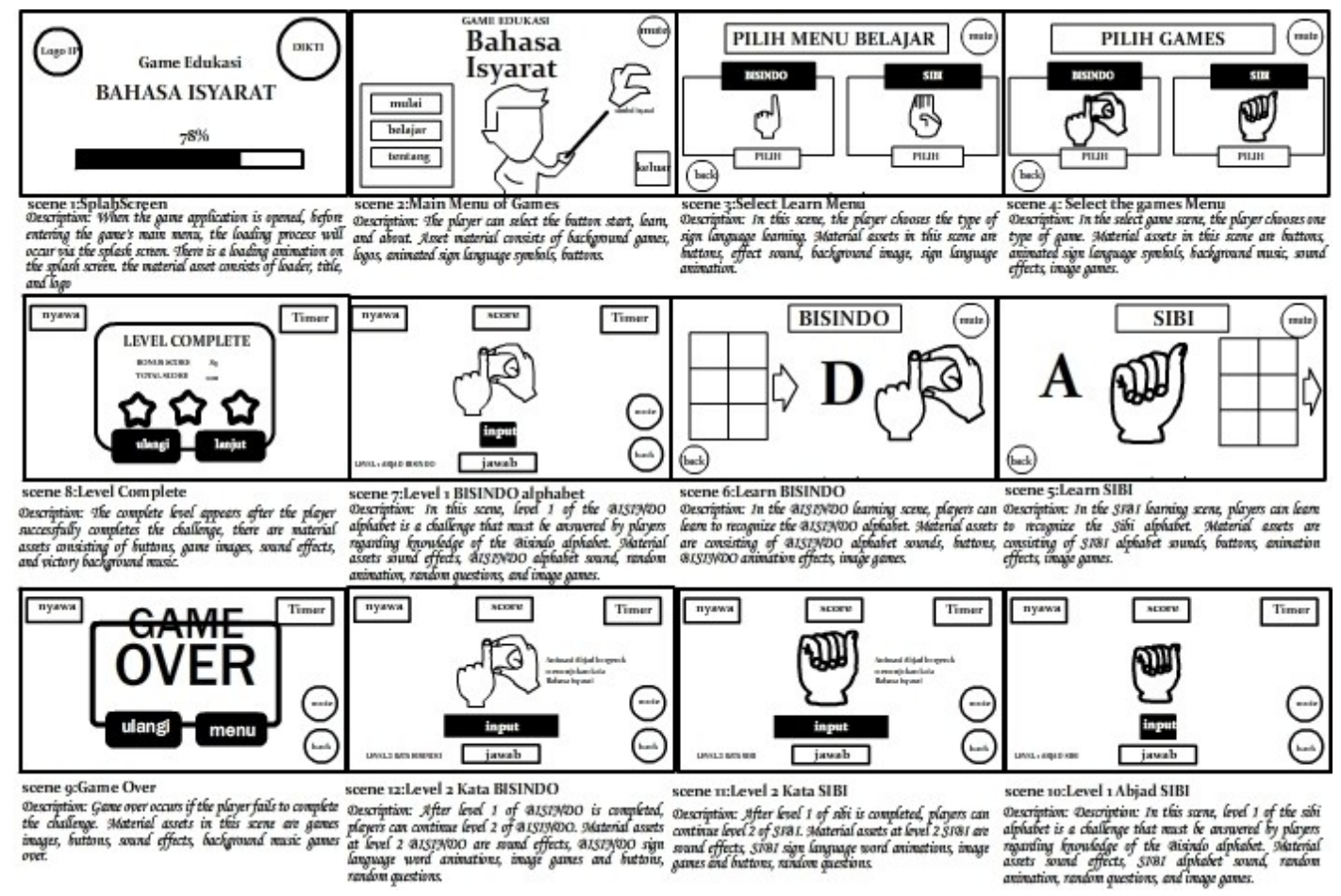

Fig. 2 Sign language educational game storyboard

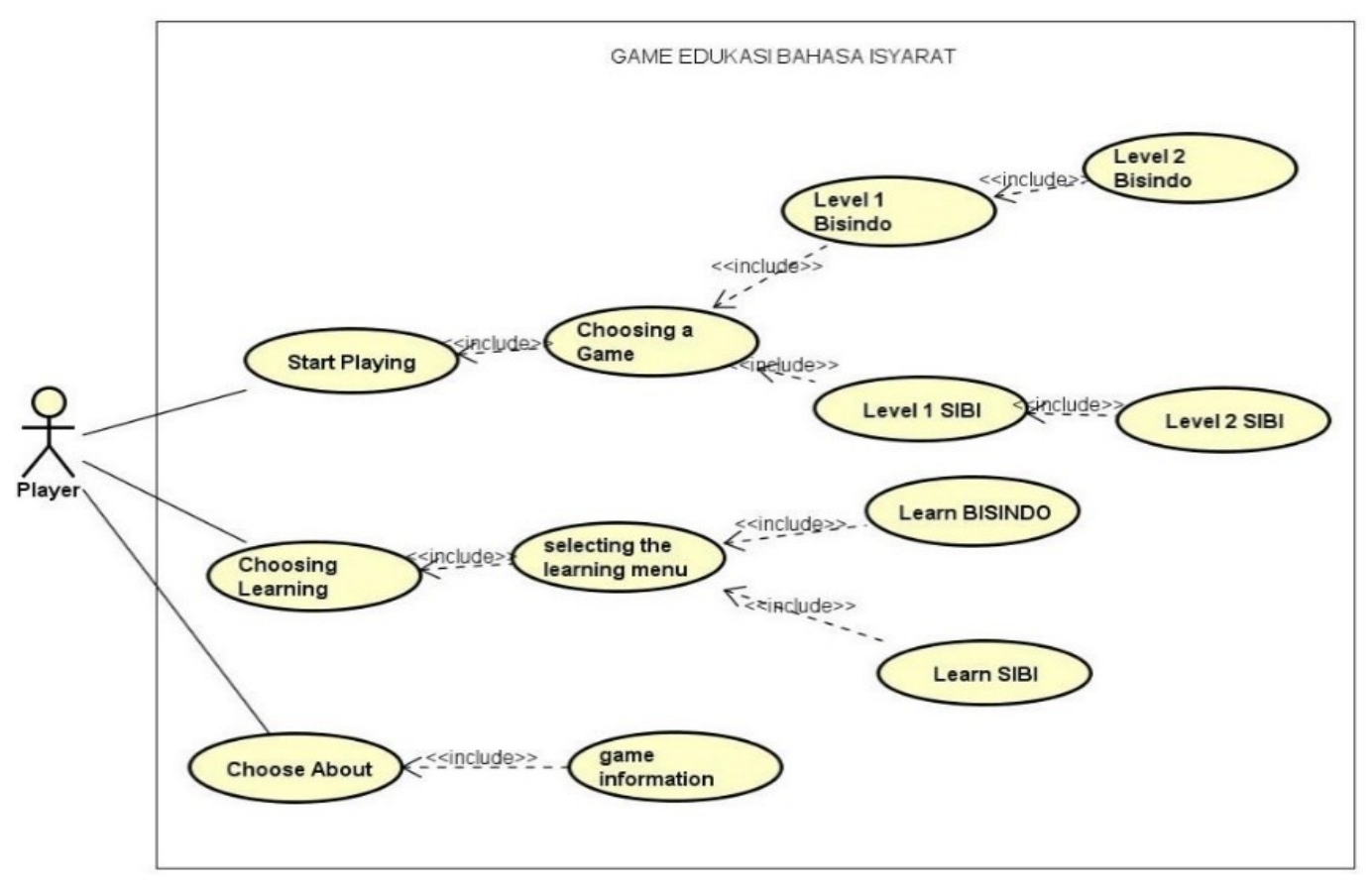

Fig. 3 Use case diagram of sign language education

Fig. 3 in the use case diagram, the player selects the button to start playing the game, and then the player chooses the type of sign language game which consists of the SIBI Game and the BISINDO Game. After the player chooses one type of game, for example, the SIBI game, the game can be started from Level 1 SIBI, then the player can continue to Level 2 SIBI after the challenge at Level 1 is over. If the player chooses the 
learning button, it will be continued on the learning options menu. The learning menu consists of SIBI learning and BISINDO learning. Player will get game information such as a researcher profile by selecting the About button.

Fig. 4 shows the activity diagram starting to play a game. The player selects the start playing button. The educational game application will display select the game menu. Players choose one type of game consisting of SIBI sign language game and BISINDO sign language game. After the player selects the type of game, the player must complete the level 1 challenge in the sign language alphabets. Suppose the player succeeds in completing the game at level 1 . In that case, the educational game will display a complete level 1 dialogue and continue with level 2 sign language words. In contrast, if level 1 or level 2 fails to complete the challenge, the player can repeat the game at the same level or return to the beginning to start playing the game again on the main game menu. The last level is Level 2. If the player completes the challenge, it will display Level 2 complete along with the score.

\section{B. Production Game Development}

This phase makes the game start by creating material assets based on the product backlog and storyboard games. The development team determines what features will be made in the first sprint iteration stage based on priority. The sprint will be stopped if there is no more change and continue to the next step. The duration of the first sprint process for the actual teamwork time is 15 days, with the total hours during the first sprint is 160 hours (Table III).

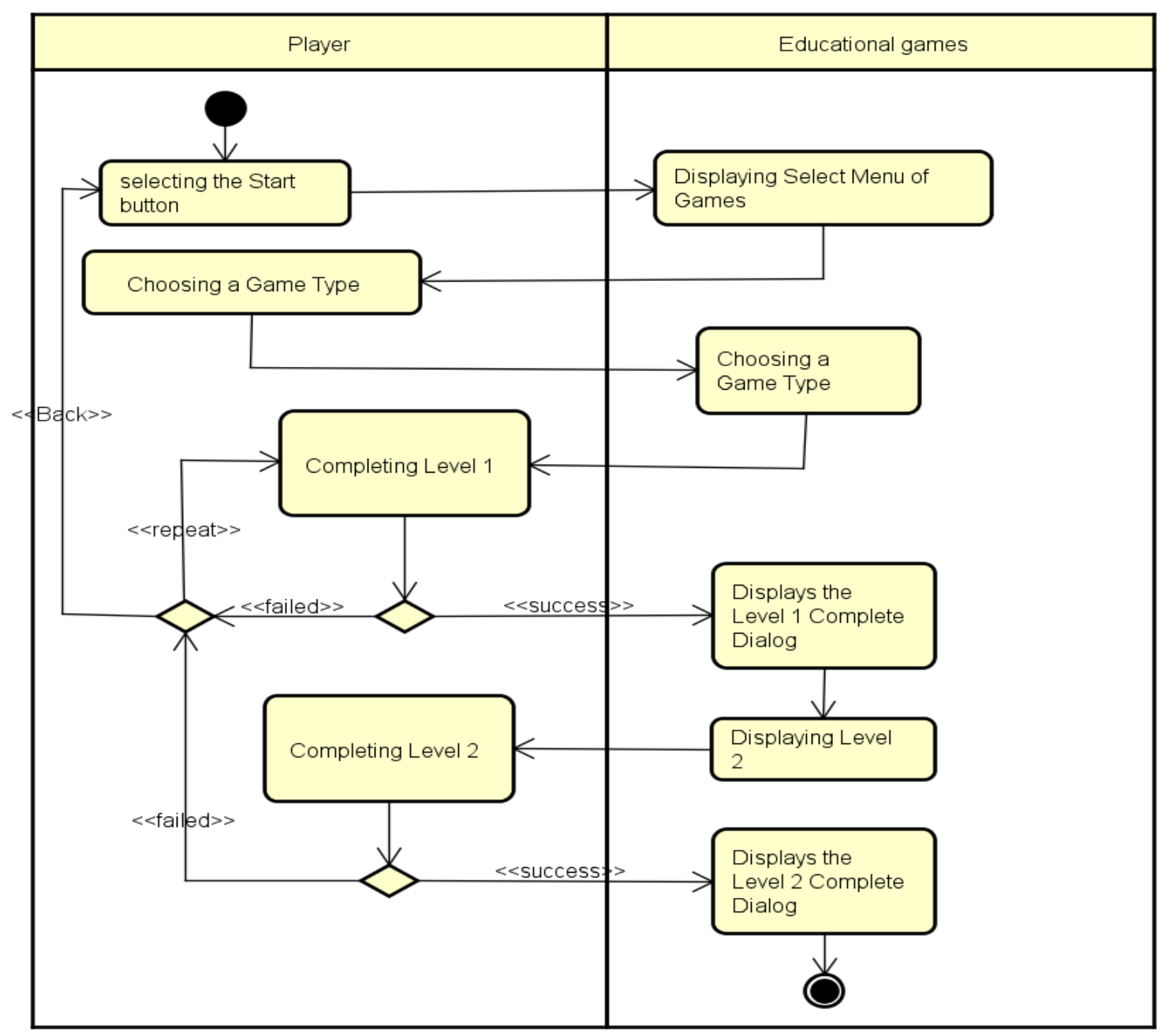

Fig. 4 Activity diagram of starting game 
TABLE III

SPRINT BACKLOG FOR THE FIRST FEATURE

\begin{tabular}{|c|c|c|c|c|c|c|c|c|c|c|c|c|c|c|c|c|c|c|c|}
\hline \multirow{2}{*}{ Id Backlog } & \multirow{2}{*}{ Scene } & \multirow{2}{*}{ Feature Name } & \multirow{2}{*}{$\begin{array}{c}\text { Total } \\
\text { Time } \\
\text { (Hours) }\end{array}$} & \multirow[b]{2}{*}{$\mathbf{0}$} & \multicolumn{15}{|c|}{ Actual teamwork time (Days) } \\
\hline & & & & & 1 & 2 & 3 & 4 & 5 & 6 & 7 & 8 & 9 & 101 & 11 & 12 & 13 & 14 & 15 \\
\hline 5 & 7 & Level 1: BISINDO alphabet & 38 & & 3 & 3 & 3 & 3 & 3 & 3 & 3 & 3 & 3 & 3 & 2 & 2 & 2 & 2 & \\
\hline 6 & 10 & Level 1: SIBI alphabet & 38 & & 3 & 3 & 3 & 3 & 3 & 3 & 3 & 3 & 3 & 3 & 2 & 2 & 2 & 2 & \\
\hline 7 & 12 & Level 2 : BISINDO Words & 38 & & & & 2 & 2 & 2 & 3 & 3 & 4 & 4 & 4 & 3 & 3 & 3 & 3 & 2 \\
\hline 8 & 11 & Level 2 :SIBI Words & 38 & & & & 2 & 2 & 2 & 3 & 3 & 4 & 4 & 4 & 3 & 3 & 3 & 3 & 2 \\
\hline 9 & 8 & Level Complete & 4 & & & & & & & & & & & & & 1 & 1 & 1 & 1 \\
\hline 10 & 9 & Game Over & 4 & & & & & & & & & & & & & 1 & 1 & 1 & 1 \\
\hline \multicolumn{3}{|c|}{ Time Remaining } & 160 & 160 & 154 & 148 & 138 & 128 & 118 & $106 \mathrm{~s}$ & 94 & 80 & 66 & 524 & 42 & 30 & 18 & 6 & 0 \\
\hline
\end{tabular}

Based on Table III of the sprint backlog, the actual work graph from the first sprint can be shown in Fig. 5, which is in a burndown chart.

Sprint backlog on the first sprint will result in a sign language educational game. The features resulting from the first sprint, namely sign language games level 1, level 2, game over, and level complete. The following is the output of the first sprint shown in Fig. 6.

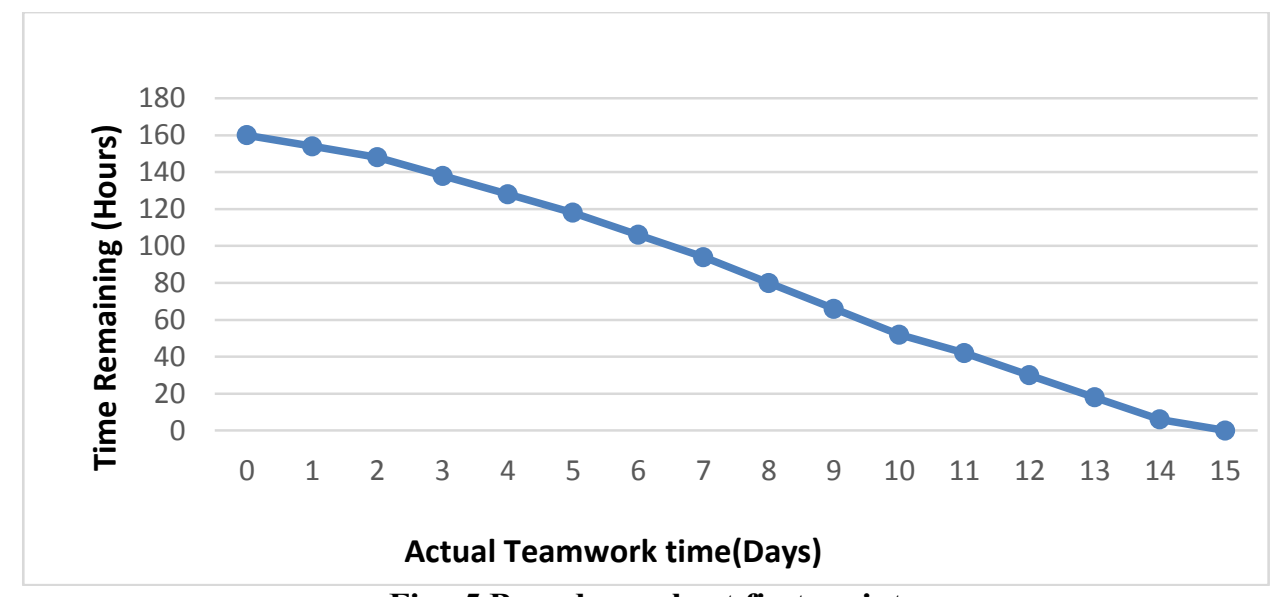

Fig. 5 Burndown chart first sprint

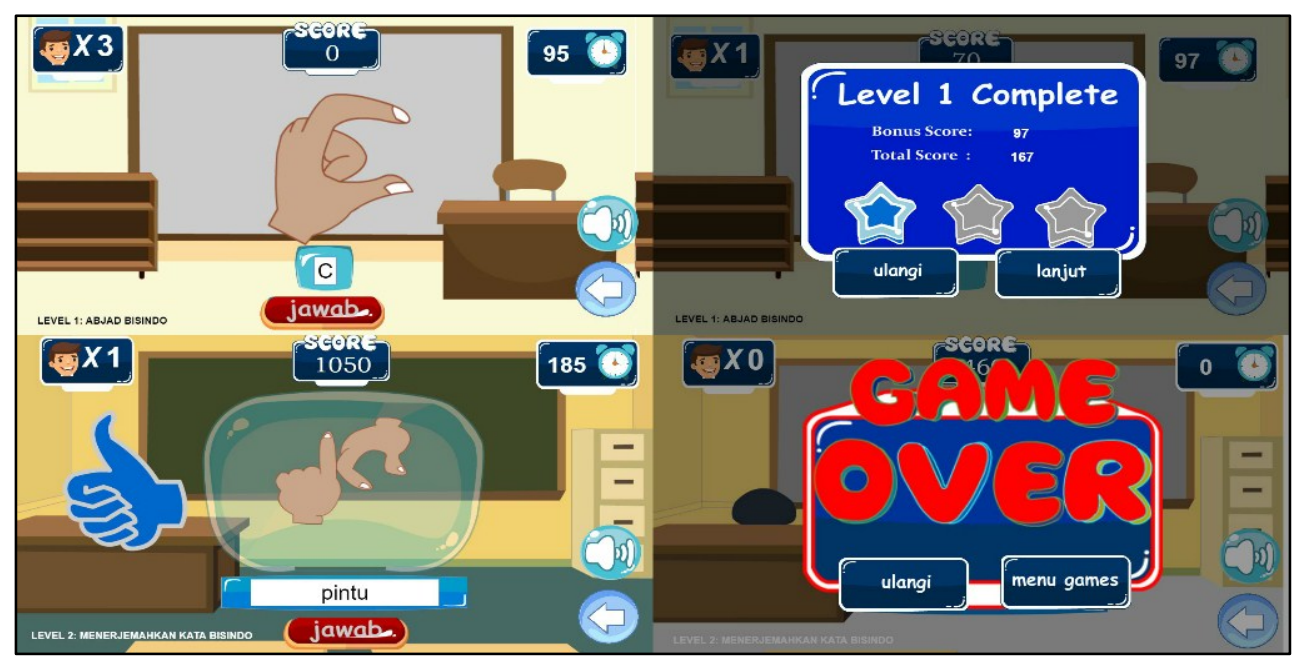

Fig. 6 First sprint output 
Sign language game levels consist of SIBI and BISINDO sign language games. There are two levels to be played, namely the first level for introducing SIBI and BISINDO alphabets with 15 questions available. The challenge at level 1 is translating the alphabet from the sign language Sibi and Bisindo, which consists of 10 questions. At the game level, the player inputs the alphabet to translate the sign language symbol. For example, if the alphabet B appears in sign language, the player must translate the sign language symbol's meaning. At level 2, the player must answer in the form of a word based on the sign language word's translation. For example, SLB words from sign language are displayed animation on a sign language symbol in which the alphabet moves alternately. The game will be more challenging if questions are provided randomly. Then the timer is added to the game with an initiation time of 100 seconds, and the initial value of the player's life is three times. Suppose the player can complete the challenge of 15 questions at level one. In that case, they will get an achievement in the form of a star based on the score obtained and continued with level two with a one life bonus, the bonus score obtained from the remaining timer multiplied by the value of 5 and a time bonus of 100 seconds. The game over message will appear when the timer runs out, or life chances are used up.

If there are no changes from the first sprint stage at the development stage, it will continue to the second sprint stage. During the second sprint process, the team's actual working time was ten days, with the total hours during the second sprint being 90 hours. The following is the second sprint shown in Table IV.

Based on Table IV of the second sprint backlog feature, the results can be interpreted into a burndown chart. The following is a burndown chart, as shown in Fig. 7.

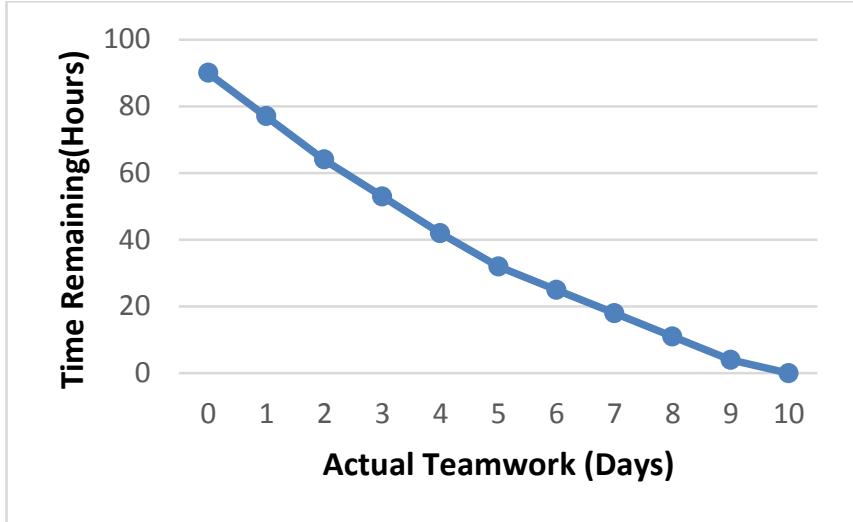

Fig. 7 Burndown chart the second sprint

The following is the second sprint output, namely learning BISINDO and SIBI, learning select menu, selecting the games menu, main games menu, and splash screen. The following is the output of the second sprint shown in Fig. 8.

TABLE IV

SPRINT BACKLOG FOR THE SECOND FEATURE

\begin{tabular}{|c|c|c|c|c|c|c|c|c|c|c|c|c|c|c|}
\hline \multirow{2}{*}{$\begin{array}{c}\text { Id } \\
\text { Backlog }\end{array}$} & \multirow{2}{*}{ Scene } & \multirow{2}{*}{ Feature Name } & \multirow{2}{*}{$\begin{array}{c}\text { Total } \\
\text { Time } \\
\text { (Hours) }\end{array}$} & \multicolumn{11}{|c|}{ Actual teamwork time (Days) } \\
\hline & & & & 0 & 1 & 2 & 3 & 4 & 5 & 6 & 7 & 89 & 91 & 10 \\
\hline 1 & 1 & Splashscreen & 5 & & 1 & 1 & 1 & 1 & 1 & & & & & \\
\hline 2 & 2 & Main Memu of Games & 13 & & 2 & 2 & 2 & 2 & 1 & 1 & 1 & 11 & 1 & \\
\hline 3 & 4 & Select the Games menu & 14 & & 2 & 2 & 2 & 2 & 2 & 1 & 1 & 11 & 1 & \\
\hline 4 & 3 & Select Learn menu & 14 & & 2 & 2 & 2 & 2 & 2 & 1 & 1 & 11 & 1 & \\
\hline 11 & 5 & SIBI Learning & 22 & & 3 & 3 & 2 & 2 & 2 & 2 & 2 & 22 & 2 & 2 \\
\hline 12 & 6 & BISINDO Learning & 22 & & 3 & 3 & 2 & 2 & 2 & 2 & 2 & 22 & 2 & 2 \\
\hline \multicolumn{3}{|c|}{ Time Remaining } & 90 & 90 & 77 & $64 \div$ & 53 & 42 & 32 & 25 & 18 & 114 & 4 & 0 \\
\hline
\end{tabular}




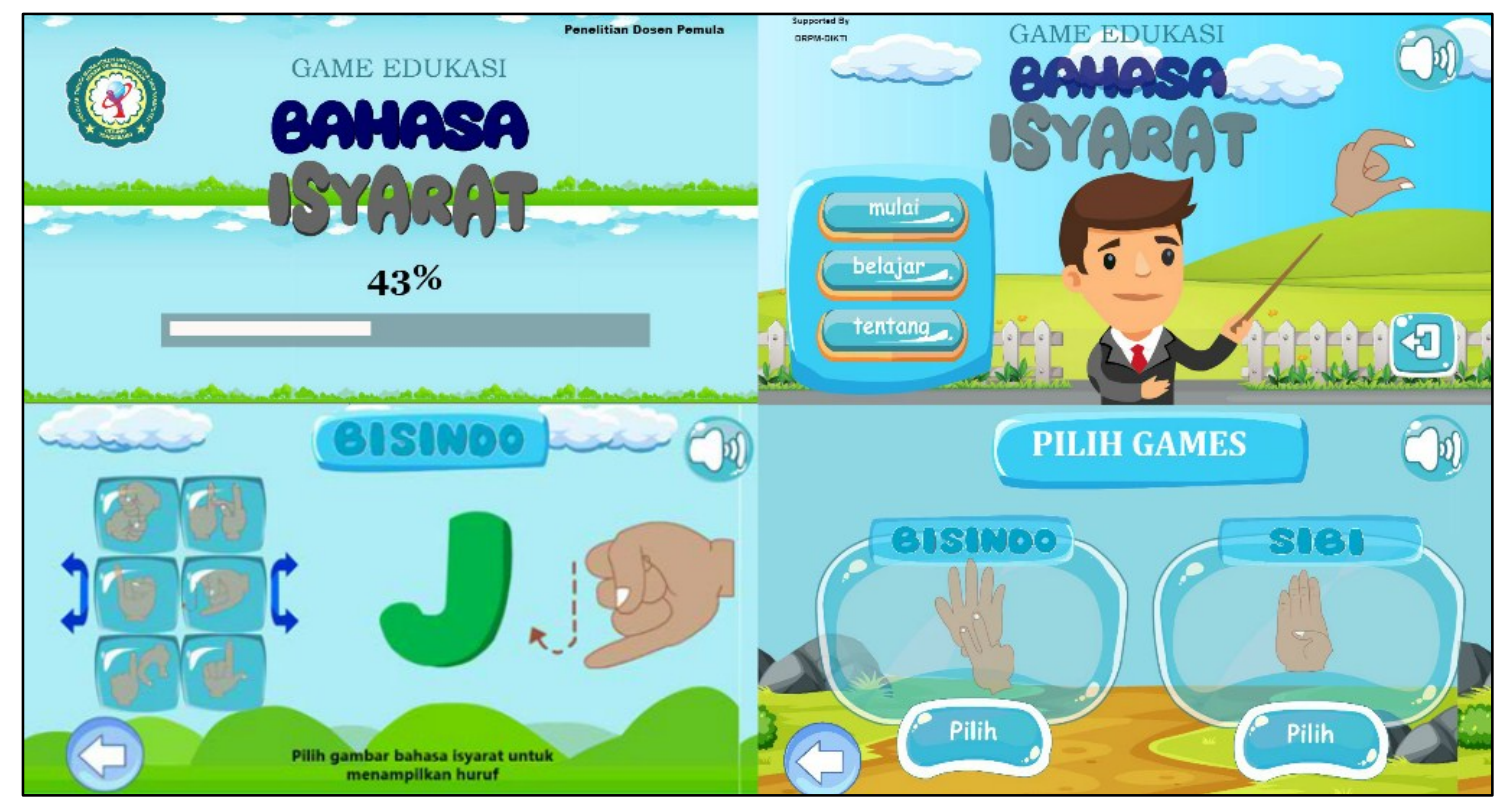

Fig. 8 Second sprint output

\section{Post-Production}

1) Blackbox Testing Results: After the finished game is created following the product backlog, it is tested based on functionality (black-box testing).
Testing is carried out directly using an Android device with a minimum system requirement of Android 5.0 (Lollipop). The test results are based on game functionality shown in Table V.

TABLE V

FUNCTIONALITY TESTING

\begin{tabular}{|c|c|c|c|c|c|c|}
\hline No & Test Name & Test Case Input & Pre-Condition & Expected Result & Actual Result & Status \\
\hline 1 & $\begin{array}{l}\text { Splash } \\
\text { screen }\end{array}$ & $\begin{array}{l}\text { open the Sign } \\
\text { Language } \\
\text { Educational } \\
\text { Games app }\end{array}$ & $\begin{array}{l}\text { Players open sign } \\
\text { language } \\
\text { educational } \\
\text { games. }\end{array}$ & $\begin{array}{l}\text { After loading is } \\
\text { complete, enter the } \\
\text { main game menu }\end{array}$ & $\begin{array}{l}\text { Loading is } \\
\text { complete and } \\
\text { entering the main } \\
\text { game menu }\end{array}$ & Valid \\
\hline \multirow[t]{2}{*}{2} & Answers & $\begin{array}{l}\text { Wrong Answer } \\
\text { input }\end{array}$ & $\begin{array}{l}\text { The player is at a } \\
\text { level of the game }\end{array}$ & $\begin{array}{l}\text { Life point reduced by } \\
\text { one }\end{array}$ & $\begin{array}{l}\text { Life point reduced } \\
\text { by one }\end{array}$ & Valid \\
\hline & & $\begin{array}{l}\text { Correct Answer } \\
\text { input }\end{array}$ & $\begin{array}{l}\text { The player is at a } \\
\text { level of the game }\end{array}$ & $\begin{array}{l}\text { Score increases by } 10 \\
\text { points }\end{array}$ & $\begin{array}{l}\text { Score increases by } \\
10 \text { points }\end{array}$ & Valid \\
\hline 3 & Life & life $=0$ & $\begin{array}{l}\text { The player is at a } \\
\text { level of the game }\end{array}$ & $\begin{array}{l}\text { Displays the Game } \\
\text { Over Dialog }\end{array}$ & $\begin{array}{l}\text { Displays the Game } \\
\text { Over Dialog }\end{array}$ & Valid \\
\hline \multirow[t]{2}{*}{4} & Timer & Timer $>=0$ & $\begin{array}{l}\text { The player is at a } \\
\text { level of the game }\end{array}$ & $\begin{array}{l}\text { The running timer is } \\
\text { reduced by } 1 \text { second }\end{array}$ & $\begin{array}{l}\text { The running timer } \\
\text { is reduced by } 1 \\
\text { second }\end{array}$ & Valid \\
\hline & & Timer $==0$ & $\begin{array}{l}\text { The player is at a } \\
\text { level of the game }\end{array}$ & $\begin{array}{l}\text { Displays the Game } \\
\text { Over Dialog }\end{array}$ & $\begin{array}{l}\text { Displays the Game } \\
\text { Over Dialog }\end{array}$ & Valid \\
\hline 5 & $\begin{array}{l}\text { Games } \\
\text { Questions }\end{array}$ & Questions $=0$ & $\begin{array}{l}\text { The player is at a } \\
\text { level of the game }\end{array}$ & $\begin{array}{l}\text { Displays the Complete } \\
\text { Level Dialog }\end{array}$ & $\begin{array}{l}\text { Displays the } \\
\text { Complete Level } \\
\text { Dialog }\end{array}$ & Valid \\
\hline 6 & $\begin{array}{l}\text { Active } \\
\text { Learning } \\
\text { Menu }\end{array}$ & $\begin{array}{l}\text { Touch the Sign } \\
\text { Language } \\
\text { Alphabet button }\end{array}$ & $\begin{array}{l}\text { The player is at } \\
\text { the active learning } \\
\text { level }\end{array}$ & $\begin{array}{l}\text { Displays the translation } \\
\text { and makes the sound of } \\
\text { the displayed alphabet } \\
\text { letters }\end{array}$ & $\begin{array}{l}\text { Displays the } \\
\text { translation and } \\
\text { makes the sound of } \\
\text { the displayed } \\
\text { alphabet letters }\end{array}$ & Valid \\
\hline
\end{tabular}


Based on Table V black box testing results, it can be concluded that the function of the sign language educational game features can run normally.

2) Usability Testing Results: Usability testing was carried out to obtain feedback on the quality of the game experience from users. The test was carried out by 23 deaf student respondents at the State Special School in Banjar through special assistance by sign language teachers and 23 non-disabled respondents, including the teachers and deaf students' relatives Banjar. The usability testing questionnaire was tested for validity and reliability using SPSS software. Question items would be declared valid if the calculated value of $r$ was greater than the $r$ table. If the $r$ count was smaller than the $r$ table, then it was declared invalid. The reliability test was used to determine which variables were reliable with the terms Cronbach Alpha $(\alpha)>0.60$ [21]. The validity testing process was carried out on 23 respondents at a significance level $(\alpha)$ of $5 \%$ so that the $r$ table obtained was 0.423 . The aspects tested are based on Nielsen's criteria, namely learnability, efficiency, memorability, errors, and satisfaction. The following are the validity test results, which can be shown in Table VI, and the usability reliability test is shown in Table VII.

Based on Table VII, it can be concluded that the validity result of the calculated r-value greater than 0.413 ( $\mathrm{r}$ Table) is valid. The reliability test results at Cronbach's Alpha value $>0.60$ then concluded that the variable is reliable.

The usability testing results based on the respondent's value Likert scale can be shown in Table VIII. R1 shows deaf students of State Special School Banjar and R2 are non-disabled.

Usability testing results from efficiency, memorability, and error can be concluded as good because the percentage of the average value is at a value of $61 \%-80 \%$. The learnability and satisfaction aspects produce an average score of $81 \%-100 \%$, so the conclusion is excellent. Based on the average overall usability test results, the sign language education game created is classified as suitable for deaf students from Banjar State Special School and non-disabled people who want to learn sign language.

TABLE VI

USABILITY VALIDITY TEST

\begin{tabular}{|c|c|c|c|c|}
\hline Aspects & Item & $\begin{array}{c}\mathbf{r} \\
\text { Calculate }\end{array}$ & $\begin{array}{c}\mathbf{r} \\
\text { Table }\end{array}$ & Conclusion \\
\hline \multirow{5}{*}{ Learnability } & 1. Can text be read clearly? & 0,882 & 0,413 & Valid \\
\hline & 2. The initial display of the game is easy to recognize & 0,835 & 0,413 & Valid \\
\hline & 3. The available buttons are easy to use & 0,915 & 0,413 & Valid \\
\hline & 4. Starting the game is easy & 0,862 & 0,413 & Valid \\
\hline & 5. Ease of game installation & 0,759 & 0,413 & Valid \\
\hline \multirow{2}{*}{ Efficiency } & 1. Loading speed on the menu & 0,956 & 0,413 & Valid \\
\hline & 2 Is the response to the answer displayed quickly? & 0,936 & 0,413 & Valid \\
\hline \multirow{3}{*}{ Memorability } & 1.Feature function easy to remember & 0,946 & 0,413 & Valid \\
\hline & 2.Easy to remember button names & 0,916 & 0,413 & Valid \\
\hline & 3. Easy to remember the gameplay & 0,758 & 0,413 & Valid \\
\hline \multirow{2}{*}{ Errors } & 1. Are features working correctly? & 0,926 & 0,413 & Valid \\
\hline & 2. How is the error level of the installation process? & 0,937 & 0,413 & Valid \\
\hline \multirow{3}{*}{ Satisfaction } & 1. Do you get an understanding of sign language from the game? & 0,834 & 0,413 & Valid \\
\hline & 2. Is the game presented interesting? & 0,817 & 0,413 & Valid \\
\hline & 3. Do you want to play educational games again? & 0,739 & 0,413 & Valid \\
\hline
\end{tabular}

TABEL VII

USABILITY RELIABILITY TEST

\begin{tabular}{ccc}
\hline Aspects & Cronbach's Alpha & N of Items \\
\hline Learnability & 0.9 & 5 \\
Efficiency & 0.88 & 2 \\
Memorability & 0.848 & 3 \\
Errors & 0.846 & 2 \\
Satisfaction & 0.714 & 3 \\
\hline
\end{tabular}


TABLE VIII

EDUCATIONAL GAME USABILITY TESTING

\begin{tabular}{|c|c|c|c|c|c|}
\hline \multirow{2}{*}{$\begin{array}{l}\text { Nielsen's criteria } \\
\text { Learnability }\end{array}$} & \multicolumn{2}{|c|}{ R1 } & \multicolumn{2}{|c|}{$\mathbf{R 2}$} & \multirow[t]{2}{*}{ Category } \\
\hline & & \multirow{6}{*}{$82,43 \%$} & & \multirow{6}{*}{$81,04 \%$} & \\
\hline Can text be read clearly? & $85,22 \%$ & & $86,09 \%$ & & \multirow{5}{*}{ Excellent } \\
\hline The initial display of the game is easy to recognize & $88,70 \%$ & & $83,48 \%$ & & \\
\hline The available buttons are easy to use & $81,74 \%$ & & $79,13 \%$ & & \\
\hline Starting the game is easy & $80,87 \%$ & & $79,13 \%$ & & \\
\hline Ease of game installation & $75,65 \%$ & & $77,39 \%$ & & \\
\hline \multicolumn{6}{|l|}{ Efficiency } \\
\hline Loading speed on the menu & $72,17 \%$ & \multirow[t]{3}{*}{$71,74 \%$} & $73,04 \%$ & \multirow[t]{2}{*}{$73,91 \%$} & \multirow[t]{3}{*}{ Good } \\
\hline Is the response to the answer displayed quickly? & $71,30 \%$ & & $74,78 \%$ & & \\
\hline Memorability & & & & \multirow{4}{*}{$77,68 \%$} & \\
\hline Feature function easy to remember & $75,65 \%$ & \multirow{3}{*}{$75,36 \%$} & $77,39 \%$ & & \multirow{3}{*}{ Good } \\
\hline Easy to remember button names & $71,30 \%$ & & $74,78 \%$ & & \\
\hline Easy to remember the gameplay? & $79,13 \%$ & & $80,87 \%$ & & \\
\hline Errors & & & & \multirow{4}{*}{$82,61 \%$} & \multirow{3}{*}{ Good } \\
\hline Are features working correctly? & $80,00 \%$ & \multirow{3}{*}{$79,13 \%$} & $80,00 \%$ & & \\
\hline How is the error level of the installation process? & $78,26 \%$ & & $85,22 \%$ & & \\
\hline Satisfaction & & & & & \multirow{4}{*}{ Excellent } \\
\hline Do you get an understanding of sign language from the game? & $78,26 \%$ & \multirow{3}{*}{$81,16 \%$} & $81,74 \%$ & \multirow{3}{*}{$83,48 \%$} & \\
\hline Is the game presented interesting? & $84,35 \%$ & & $88,70 \%$ & & \\
\hline Do you want to play educational games again? & $80,87 \%$ & & $80,00 \%$ & & \\
\hline
\end{tabular}

\section{CONCLUSION}

Based on the results and discussions, it can be concluded that the SCRUM approach can be implemented in creating sign language education games. There are two iterations of sprints produced, namely the first iteration sprint and The second sprint iteration. The first sprint iteration was conducted for 15 days and resulted in level 1 and 2 features for the SIBI and BISINDO alphabets, Level Complete, and Game Over. The second sprint iteration was conducted for ten days and resulted in splash screen features, SIBI learning, BISINDO learning, Main Menu, Game Type Select Menu, and Select Learning Menu. Testing usability based on efficiency, memorability, and error results in good conclusions. Aspects of satisfaction and learnability get an excellent conclusion. Overall the average usability test has been good, so it is suitable for deaf children in SLB Banjar (State Special School Banjar) and non-disabled who want to learn sign language.

\section{ACKNOWLEDGMENT}

Thanks to the Directorate of Research and Community Service (DRPM) for the opportunity and support of research funds for the Beginner Lecturer Research Scheme (PDP) for the Fiscal Year 2020 based on Decree No. 26/E1/KPT/2020 and Agreement/Contract Number 080/SP2H/AMD/LT/DRPM/2020;051/SP2H/AMD/LT MONO/LL4/2020;08/LPPM/STMIKIP/X/2020.

\section{REFERENCES}

[1] D. Gumulya and F. Ho, "Penelitian perancangan sarana bantu belajar bahasa untuk anak tunarungu dengan pendekatan participatory design," Prod. J. Desain Prod. (Pengetahuan dan Peranc. Produk), vol. 3, no. 6, pp. 197-206, 2019, doi: 10.24821/productum.v3i6.2265.

[2] G. Gumelar, H. Hafiar, and P. Subekti, "Bahasa Isyarat Indonesia Sebagai Budaya Tuli Melalui Pemaknaan Anggota Gerakan Untuk Kesejahteraan Tuna Rungu," Inf. Kaji. Ilmu Komun., vol. 48, no. 1, pp. 65-78, 2018.

[3] E. Zulpicha, "Konflik Kebijakan Penggunaan Sistem Bahasa Isyarat Indonesia Di Lingkungan Pendidikan Formal," J. Anal. Sosiol., vol. 6, no. 1, 2017, doi: 10.20961/jas.v6i1.18190.

[4] V. Palera, N. Anriani, and C. A. H. F. Santosa, "Pengaruh Model Blended-Learning Berbantuan Video Interaktif terhadap Kemampuan Pemecahan Masalah Matematis Siswa," vol. 1, no. 2, pp. 103-116, 2019.

[5] F. Y. Al Irsyadi, D. Puspitassari, and Y. I. Kurniawan, "ABAS (Ayo Belajar Sholat): Game Edukasi Pembelajaran Sholat Untuk Anak Tuna Rungu Wicara," J. Manaj. Inform., vol. 9, no. 1, pp. 17-28, 2019, doi: 10.34010/jamika.v9i1.1537. 
[6] D. C. Jauharul Khikam Hikmalansya, "Aplikasi Pembelajaran Bahasa Isyarat Berbasis Android," INFORM, vol. 1, no. 2, pp. 118-124, 2016, doi: http://dx.doi.org/10.25139/inform.v1i2.849.

[7] A. D. Qoyyimah and E. P. Adi, “Aplikasi Permainan Berbasis Android dalam Meningkatkan Kemampuan Kosakata Anak Tunarungu," J. ORTOPEDAGOGIA, vol. 3, no. 2, pp. 81-86, 2017, doi: 10.17977/um031v3i22017p081.

[8] M. B. Misbah, A. Hakim, H. Tolle, and A. P. Kharisma, "Pengembangan Aplikasi Pelatihan Bahasa Pada Tunarungu Menggunakan Google Speech Berbasis Android," J. Pengemb. Teknol. Inf. dan Ilmu Komput. Univ. Brawijaya, vol. 3, no. 2, pp. 8813-8822, 2019.

[9] C. E. Prastio and N. Ani, "Aplikasi Self Service Menu Menggunakan Metode Scrum Berbasis Android ( Case Study: Warkobar Café Cikarang )," J. PETIR, vol. 11, no. 2, pp. 203-220, 2018.

[10] I. Mahendra and deny tresno eby Yanto, "Agile Development Methods Dalam Pengembangan Sistem Informasi Pengajuan Kredit Berbasis Web (Studi Kasus : Bank Bri Unit Kolonel Sugiono)," Jurnalteknologi Dan Open Source, vol. 1, no. proses pengajuan kredit pada Bank BRI Unit Kolonel Sugiono masih dilakukan secara manual., pp. 13, 14, 15, 2018.

[11]R. Popli and N. Chauhan, "Scrum: an Agile Framework," Int. J. Inf. Technol., vol. 4, no. 1, pp. 147-149, 2011, [Online]. Available: http://csjournals.com/IJITKM/PDF 4-1/30.Rashmi Popli1 \& Naresh Chauhan2.pdf.

[12] R. R. Santika, K. Ramadhan, M. Andri, A. Solehuddin, and S. Juanita, "Implementasi Game Edukasi Belajar Bahasa Inggris Dengan Metode Game Development Life Cycle Dan Pendekatan Taksonomi Bloom," J. Univ. Budi Luhur, no. c, pp. 392-402, 2019.

[13] S. Sauda, N. Oktaviani, and M. Bunyamin, "Implementasi Metode Scrum Dalam Pengembangan Test Engine Try Out Sertifikasi," JISKA (Jurnal Inform. Sunan Kalijaga), vol. 3, no. 3, pp. 70-78, 2019, doi: 10.14421/JISKA.2019.\%X.

[14] I. S. Indriani Widiastuti Nelly, "Membangun Game Edukasi Sejarah WALISONGO Jurnal Ilmiah Komputer dan Informatika ( KOMPUTA )," J. Ilm. Komput. dan Inform., vol. I, no. 2, pp. 41-48, 2012.

[15] Suendri, "Implementasi Diagram UML (Unified Modelling Language) Pada Perancangan Sistem Informasi Remunerasi Dosen Dengan Database Oracle (Studi Kasus: UIN Sumatera Utara Medan)," J. Ilmu Komput. dan Inform., vol. 3, no. 1, pp. 1-9, 2018, [Online]. Available: http://jurnal.uinsu.ac.id/index.php/algoritma/article/dow nload/3148/1871.

[16] M. Hidayat, T., \& Muttaqin, "Pengujian Sistem Informasi Pendaftaran dan Pembayaran Wisuda Online menggunakan Black Box Testing dengan Metode Equivalence Partitioning dan Boundary Value Analysis," J. Tek. Inform. UNIS JUTIS, vol. 6, no. 1, pp. 22525351, 2018, [Online]. Available: www.ccssenet.org/cis.

[17] F. Adnan, B. Prasetyo, and N. Nuriman, "Usability Testing Analysis On The Bana Game as Education Game Design References on Junior High School," $J$. Pendidik. IPA Indones., vol. 6, no. 1, pp. 88-94, 2017, doi: 10.15294/jpii.v6i1.9597.

[18] S. F. C. Haviana, "Sistem Informasi Angket Pengukuran Skala Kebutuhan Materi Pembelajaran Tambahan Sebagai Pendukung Pengambilan Keputusan Di Sekolah Menengah Atas Menggunakan Skala Likert," Transistor Elektro dan Inform., vol. 1, no. 2, pp. 1-12, 2016, doi: 10.22146/gamajop.47966.

[19] T. N. Sari, "Analisis Kualitas Dan Pengembangan Sistem Informasi Akademik Berbasis Web Menggunakan Standard Iso 9126," JIKO (Jurnal Inform. dan Komputer), vol. 1, no. 1, pp. 1-7, 2016, doi: 10.26798/jiko.2016.v1i1.15.

[20] R. M. P. Siregar and E. Sudarmilah, "Rancang Bangun Virtual Reality Educational Game Penanggulangan Sampah berbasis Android untuk Anak Usia Sekolah Dasar," JUITA J. Inform., vol. 7, no. 1, p. 49, 2019, doi: 10.30595/juita.v7i1.4315.

[21] M. K. Anam and H. Ulayya, "Implementasi dan Analisa SARDrive Sebagai Media Penyimpanan Cloud," JUITA J. Inform., vol. 8, no. 1, p. 83, 2020, doi: 10.30595/juita.v8i1.5748. 
JUITA: Jurnal Informatika e-ISSN: 2579-8901; Vol. 9, No. 1, May 2021 